\title{
The Sugarcane Farmers at Keling Village in Kepung Sub-District
}

\author{
Ah. Sulhan Fauzi, Yasinta Sindy Pramesti, Hesti Istiqlaliyah, and Fatkur Rhohman \\ \{sulhanfauzi@unpkediri.ac.id\} \\ Faculty of Engineering, University of Nusantara PGRI Kediri
}

\begin{abstract}
The sweetness of sugar is not always as sweet as the fate of sugarcane farmers. The high price of sugar does not necessarily make the farmers also get high income. This is due to the absence of a definite benchmark price of sugarcane. Most of our sugarcane farmers adhere to the pattern of sugarcane planting in partnership with a sugar factory. The price of sugarcane is determined by the factory based on its yield, the higher the yield, the higher the price of sugarcane. Most of sugarcane farmers in Keling village, Kepung sub-district, Kediri district, apply a partnership pattern with the factory. This partnership pattern is in the form of revenue sharing from processed sugarcane. The average percentage for the results is 70-30, which means that from the results of processing sugarcane, farmers get $70 \%$ and $30 \%$ factory. Theoretically, the partnership pattern greatly benefits sugarcane farmers. However, it turns out that there are still many farmers who have not enjoyed the benefits of this pattern. Meanwhile, several sugarcane farmers in the Kandat sub-district of Kediri district, many of which have processed their own sugar into sugar. According to them, by processing their own sugar, instead of increasing income, they can also open jobs for local residents and the waste can be used as fuel and compost. As a consequence, we will try to provide training in making sugarcane for sugarcane farmers in Keling village so that they can process their own sugarcane to increases their income, and as a model is sugarcane farmers in Kandat subdistrict.
\end{abstract}

Keywords: sugarcane farmers, sugar prices, sugarcane prices, training, income

\section{Introduction}

East Java is the largest sugar producing region in Indonesia, $45.06 \%$ of national sugar production comes from East Java [1]. Nusantara Plantation Limited Company (PTPN) X, which is a state-owned plantation company, noted in 2016, it had produced 475,000 tons of sugar [2]. The sugar production originated from an area of 70,301 hectares spread across various regions of East Java and milled in eleven sugar mills spread across Mojokerto, Sidoarjo, Jombang, Nganjuk, Kediri and Tulungagung districts [3]. The high price of sugar does not deal with the high income of sugarcane farmers. Sugarcane farmers in Keling village, Kepung sub-district, Kediri district also do not enjoy the high price of sugar. They do not feel their income increased since the sugarcane was directly sold to the factory or to middlemen, with the selling price of sugarcane given by the factory based its 'rendemen' (yield value). The yield value is the percentage of sugar content in sugarcane. Sugarcane rendemen related to the age of sugarcane cutting [4] . If the yield is $10 \%$, it means that the sugar that will be produced is $10 \%$ from the total sugarcane weight, for example $100 \mathrm{~kg}$ of sugarcane will be produced 10 
$\mathrm{kg}$ of sugar. Geographically, the Keling area, Kepung sub-district has very good land and is suitable for sugarcane, because it has a sandy soil structure due to the eruption of Mount Kelud. The value of sugarcane yield in this area should be more than $8 \%$, but the farmers have received a yield of never more than $8 \%$ so far.

Meanwhile, in Kandat sub-district, many sugarcane farmers have processed their own sugarcane into sugar. Like in Cendono village, some sugarcane farmers have processed their sugarcane into sugar which is ready for consumption or ready for sale and is also ready to be processed again to be used as ingredients for making soy sauce, coconut sugar and ant sugar or used as one of the ingredients in the food/ beverage industry. But not all sugarcane is processed by themselves, they process the sugar themselves if the yield is high, it is usually above $8 \%$, if the yield is below $8 \%$, they sell it to the factory, because the operational costs are higher than the income. Sugar processing plant owned by sugarcane farmers in Cendono village, Kandat sub-district can be seen in Figure 1.

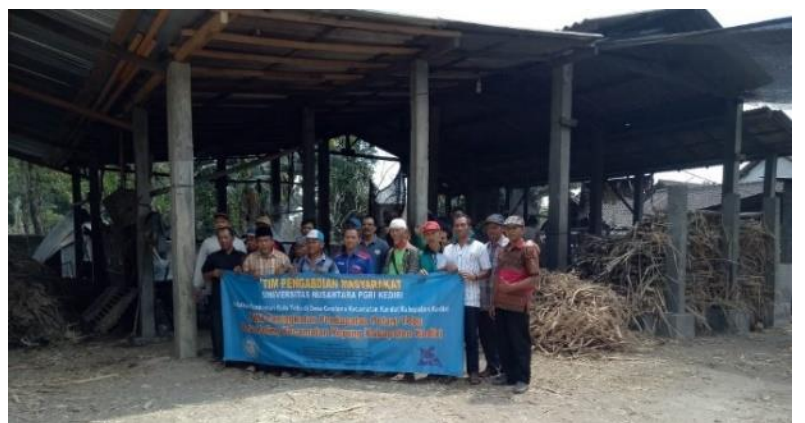

Fig. 1. The situation of sugarcane milling/ processing in the Cendono village

\subsection{Problems}

Based on the analysis of the situation in the first partner, namely sugarcane farmers in Keling village, it was agreed that there would be a number of problems that would be tried to be solved or a solution to be found, namely:

a) Sugarcane farmers' income is relatively low. According to some sugarcane farmers in Keling village who have their own sugarcane fields, lately the yields obtained can hardly be sufficient to cover the operational costs of planting.

b) There is lack of knowledge and skills of sugarcane farmers about sugarcane processing, so that farmers directly sell their crops to middlemen or are sent directly to sugar mills to get their 'share of yields'.

c) There is lack of insight into sugarcane farmers about the prospect of sugar, especially brown sugar, so farmers are less interested in processing their own sugarcane into sugar.

\subsection{Solution}

The solutions offered from several partner problems are:

a) Increasing the income of sugarcane farmers in the Keling area, Kepung sub-district, Kediri district by providing training in the processing of making brown sugar. The analysis of brown sugar processing business are, the investment costs for the 
procurement of milling land, machinery and equipment are around 50 million. The operational costs needed include costs for cutting, transporting, labour in grinding, fuel and supplementary materials. In one day, one mill is able to process sugarcane about 3 times processed/ cooking. One time cooking can process about 1.5 tons of sugarcane. If one process can produce $150 \mathrm{~kg}$ of brown sugar, then it can be obtained $450 \mathrm{~kg}$ of brown sugar in one day. With the lowest selling price of brown sugar 7,500 thousand rupiah per kilogram, farmers can get gross income of 3,375 million rupiah per day. If the operational costs of planting and processing sugarcane for 1 hectare of land are around 20 million, the sugarcane farmers can profit around 13.75 million rupiah per hectare. If it is directly sold to middlemen, 1 ha is usually valued at 30 million, so if it is reduced by operational costs, the farmer gets an increase of around 3.75 million, there is an increase in profit of around $24 \%$ of the profit by selling the sugar directly. With an investment of 50 million, this business has been able to return capital if it is processing more than 3 hectares of sugarcane land, assuming farmers have their own land and mill.

b) Providing knowledge and skills on how to make brown sugar from sugarcane. It starts from the selection of good sugarcane, preparation of equipment, the manufacturing process from the start, namely grinding, to finally producing brown sugar ready for consumption or ready to be marketed and also explained the marketing method.

c) Providing information and insight to sugarcane farmers that the domestic need for brown sugar continues to increase. Brown sugar has several advantages, for example: it can be stored more than 2 years without experiencing changes in aroma, taste and colour if it is packaged appropriately, easily dissolved, higher selling value. On a local scale, brown sugar can be marketed to soy sauce factories, to bakery or cake factories around the Kediri city/ district. To educate the market, it can also be deposited in stores or can also use online media to reach a wider market.

\section{Methods}

The Community Partnership Program was conducted from March to August 2018 at the sugarcane farmer's house in Keling village, Kepung sub-district and in the sugarcane mill owned by sugarcane farmers in Cendono village, Kandat sub-district, both of which belonged to the Kediri district. The success of this program is largely determined by the active role of partners in the form of positive responses and partner interactions and the spirit of partners to follow each schedule given by the team. In general, the implementation of this program includes planning, implementing and evaluating programs that involve implementing teams, partners and communities around the partners.

\section{a. Planning}

The team invited representatives from partners to discuss planning the course of activities including program socialization, training, determining the schedule and place of activities and preparation of tools / materials.

\section{b. Implementation}

At this stage, it was divided into two parts. Frst, it starts with a direct meeting with the first partner as the target of activities at the home of one of the sugarcane farmers in Keling 
village. In this meeting, the team provided information about the method or method of processing sugarcane into sugar and explained all matters related with making sugarcane. The next step is the practice of making sugarcane. It is conducted at the second partner's sugarcane milling in Cendono village, Kandat sub-district, Kediri district.

\section{c. Evaluation}

The evaluation was carried out three times, namely process evaluation, evaluation of results and follow-up evaluation. The implementation of this activity did not stop until the schedule was completed, but there was still sustainability to support the successful implementation of technology transfer received by the partners during the training. The dedication team will continue to provide attention and guidance to the target partners, so that it will really have a positive impact on partners to increase their understanding and skills in processing their own sugarcane.

\section{Results and Discussion}

All of training participants, both the first partner as the training target and the second partner as companion partners were very enthusiastic and played an active role in each of the activities carried out. This can be seen from several contributions given by the participants during the activity, including: the first partner provides a place/ facility for discussion and theory activities, procuring sugarcane as material during training. The second partner with his willingness provides direction and guidance in making sugar from sugarcane. The two partners are also committed to continuing the collaboration and asking the dedication team to keep in touch by conducting supervision and providing assistance if needed.



Fig. 2. Meeting with first partners

This activity begins with the preparation of team, coordination with partners, then preparation of the chronology of training, practice and evaluation. After all preparations were completed, the team met with first partner to provide knowledge about the procedures and what was needed in processing sugarcane into brown sugar or also known as 'bathok' sugar. The team provides a theory of how the steps for processing sugarcane become sugar. The team 
also provides insight into the benefits that can be obtained if we process sugarcane itself compared to if we directly sell it to middlemen or to sugar mills.



Fig. 3. Sugarcane milling process

In the next stage, the first partner was taken to the second partner's sugarcane mill in Cendono village, Kandat sub-district, Kediri district. In this place, the first partner can see and practice directly the process of making sugarcane with direction and guidance from the second partner who has experience in making sugar for more than 9 years. At the time of practice, the sugarcane material to be processed has a $9 \%$ yield value of 1 ankle truck or approximately 5 tons.

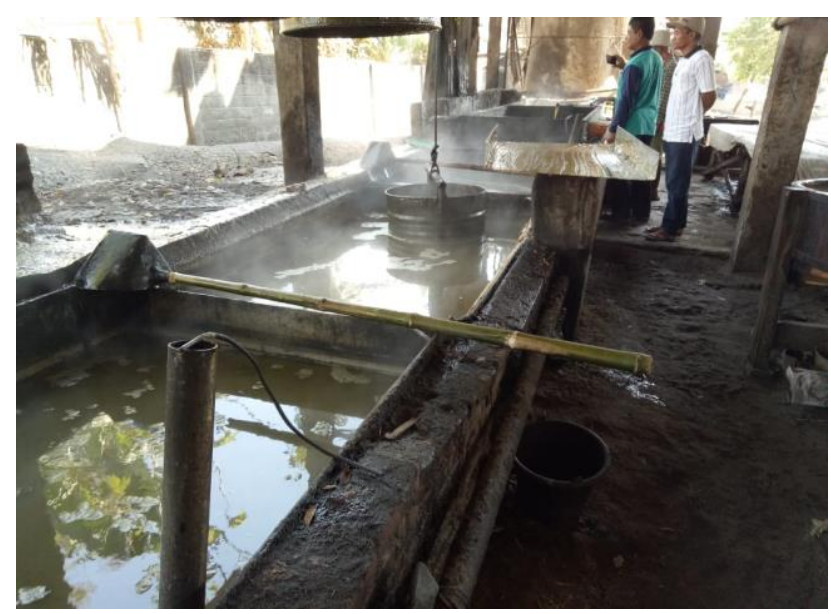

Fig. 4. Crater in 3 levels

In one day of making sugarcane, the process is usually done three times. One dish requires approximately 0.5 tons of sugarcane. The process of making sugarcane sugar is a series that cannot be interrupted, meaning that the process continues, there must be no delay or abandonment. This sugarcane mill in Cendono village is a simple example of a sugarcane processing plant, with an ideal workforce of 5 people. Each workforce has different tasks and types of work in turn, starting from sugarcane milling (figure 3), to produce sugarcane juice or 'nira'. Nira is a liquid from sugarcane milling which has a greenish brown color [5]. 
Sugarcane juice is sweet and fresh, greenish brown with $\mathrm{pH}$ 5.5-6.0. The sugarcane juice is very easily damaged so that the sugarcane becomes acidic, white-foaming, and slimy [6]. If the latex is cooked usually the color of the sugarcane juice will turn to cloudy yellowish, sour and sour. The conditions and properties of this sugarcane juice will determine the nature and quality of the product produced [7]. There are also those who are in charge to transfer of the sugarcane juice from the first cooking vessel or termed a crater, then in sequence being moved to the second crater and the third crater (figure 4). There is also the duty to clean the bagasse from the mill, keep the crater fire so it does not die and not too big, clean the sugarcane juice when cooking in each crater, and print sugar. Generally, the process of making brown sugar from sugarcane is as follows:

a) The sugarcane is cleaned and ground, then the sugarcane juice is taken.

b) The sugarcane juice is cleaned by filtering.

c) The cleaned sugarcane juice is poured into the crater and then cooked at a heating temperature of $110-120^{\circ} \mathrm{C}$ while stirring until the sugarcane juice is brown and thickens.

d) To avoid excessive foam, add coconut oil (klentik), as a decrease surface tension between foam and liquid sugarcane juice so that the bubbling discharge can prevented [8], with a ratio of 10 grams ( 1 tablespoon) to 25 liters of sugarcane juice.

e) Cooking is considered complete when the sugarcane juice is thick when put into sugarcane juice in the form of lumps or sugar fibers [9], [10].

f) Then the cooked sugarcane juice in the crater is inserted into a tub made of circular jackfruit wood for stirring and cooling (figure 5).

g) Stirring is repeated until the sugar is completely mixed, then immediately printed in 'bathok' coconut.

h) After molding, leave it to cool for about 5 minutes, then sugar can be taken/ removed from the mould by reversing the position of 'bathok'.

i) The printed sugar can be consumed, marketed or processed again.

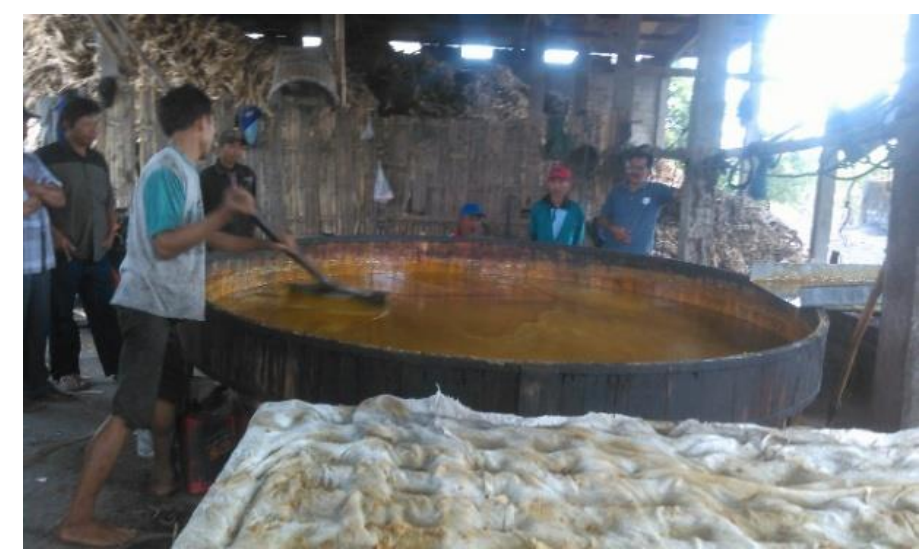

Fig. 5. Cooked sugarcane juice, stirred and ready for molding

Once the molding process is complete, immediately proceed with the next cooking process. One time the cooking process usually takes about 2 to 3 hours, depending on the size of the fire cooking stove. During the first cooking process, the first partner only sees while asking the second partner if something is not understood during the process. In the second 
cooking process, trainees (first partners) are welcome to practice it directly with the guidance of the second partners.

After completing the practice, an analysis of the benefits obtained from processing the sugarcane itself into sugar. Sugarcane ingredients weighing approximately 5 tons are cooked, producing brown sugar as much as $475 \mathrm{~kg}$ of sugar. During training, the price of sugarcane was $5,000,-/ \mathrm{kg}$, so 5 tons of sugarcane cost 2.5 million. Brown sugar at the collectors' level at that time was $7,500 / \mathrm{kg}$, so $475 \mathrm{~kg}$ of sugar was 3,562 million. We get an increase in the selling value of sugarcane by 1.062 million, for 1 truck sugarcane with a capacity of approximately 5 tons, meaning that there is an increase in farmer's income of around $15 \%$ for every 5 tons of sugarcane. The operational costs of making sugar can be covered by the sale of compost obtained from waste from the processing of sugarcane. In addition to the increase in selling value, from processing the sugarcane itself, we can provide jobs for the surrounding residents.

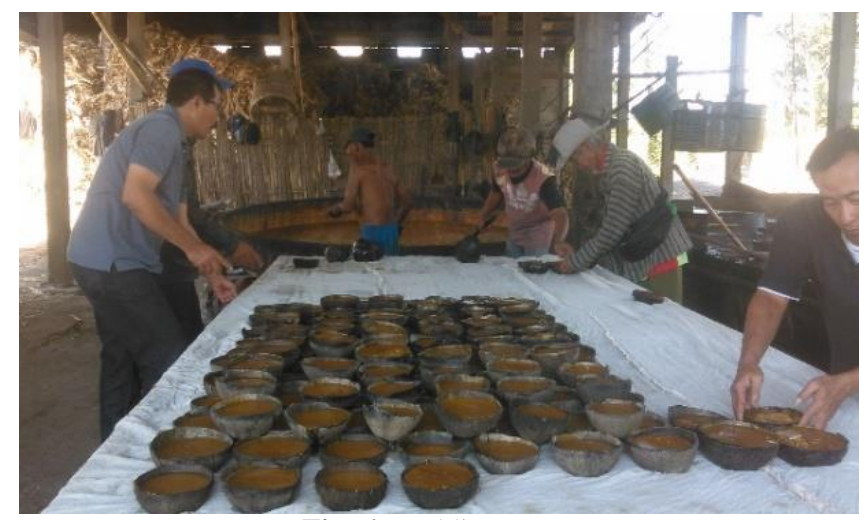

Fig. 6. Molding sugar

Furthermore, the team hopes that the target partners, namely sugarcane farmers in Keling village, can process sugarcane products independently in their respective places.

\section{Conclusion}

This PKM activity received a very good response from the Keling village community, because it increased their knowledge and insights on sugarcane farming, as well as increasing their skills in processing sugarcane, especially in making of brown sugar from sugarcane. They also understand more about the types and quality of sugarcane so that they can be used as a benchmark for determining the price of sugarcane if it is sold directly. Besides, they are also increasingly motivated to process their own sugar because they can increase their income and reduce their dependence on mills or middlemen

\section{Acknowledgements}

The authors would like to thank to The Ministry of Research Technology and Higher Education of The Republic of Indonesia for financial support for this work through project no: 045/SP2H/PPM/K7/KM/2018. 


\section{References}

[1] Indarti, Diah 2016, Outlook Tebu, Pusat Data dan Sistem Informasi Pertanian Sekretariat Jenderal Kementrian Pertanian, ISSN 1907-1507.

[2] PTPN X 2016 (online), Pertahankan Predikat Produsen Gula Terbesar di Indonesia. Diakses dari: http://ptpn10.co.id/page/predikat-produsen-gula-terbesar-di-indonesia.

[3] BPS Provinsi Jawa Timur 2015 (online), Luas Area Perkebunan Tebu. Diakses dari: https://jatim.bps.go.id/index.php/linkTabelStatis/105.

[4] Astika, I.W. 1994. Optimasi Jadwal Tanam Tebu Bagi Pabrik Gula di Lahan Kering dengan Model Optimasi Fuzzy. Tesis Fakultas Pascasarjana, IPB.

[5] Puri, B. A. 2005. Kajian Pemurnian Nira Tebu dengan Membran Filtrasi dengan Sistem Aliran Silang (Crossflow). Skripsi. Departemen Teknologi Industri Pertanian. Fakultas Teknologi Pertanian. Institut Pertanian Bogor. Bogor.

[6] Santoso, H. B. 1993. Pembuatan Gula Kelapa. Kanisius, Jakarta.

[7] Muchtadi, T. R., dan Sugiyono. 1992. Ilmu Pengetahiuan Bahan Pangan. PAU Pangan dan Gizi IPB, Bogor.

[8] Jatmika, A., M. A. Hamzzah dan D. Siahaan. 1990. Alternatif produk Olahan dari Nira kelapa. Dalam Nurlela, Euis. 2002. Kajian Faktor-faktor yang Mempengaruhi Pembentukan Warna Gula merah. Skripsi. Jurusan Teknologi Pangan dan Gizi. Fakultas Teknologi Pertanian, IPB. Bogor.

[9] Dyanti, R. 2002. Studi Komparatif Gula Merah kelapa dan Gula Merah Aren. Skripsi Jurusan Teknologi pangan dan Gizi. Fakultas Teknologi Pertanian, IPB. Bogor.

[10] Nengah, I. K. P. 1990. Kajian Reaksi Pencoklatan Termal pada Proses Pembuatan Gula merah dari Aren. Tesis. Program Studi llmu Pangan, Pasca Sarjana. IPB. 